\title{
EDUCATION PROCESS DURING THE COVID-19 LOCKDOWN: CHALLENGES IN TEACHING FOREIGN LANGUAGES
}

\author{
Oksana Babelyuk \\ Prof., DSc, Lviv State University of Life Safety, Ukraine \\ e-mail: babelyuko@gmail.com,orcid.org/0000-0003-4837-1225 \\ Nina Pavlenko
}

Ph.D. in Philology, Associate Professor at the Department of Foreign Languages,

Borys Hrinchenko Kyiv University, Ukraine

e-mail: skylangs@gmail.com,orcid.org/0000-0002-7117-1179

\author{
Aleksandra Mikus \\ MA, Polonia University in Czestochowa, Poland \\ e-mail: olafon2@interia.pl_orcid.org/0000-0003-0813-6239
}

\section{Summary}

Despite great uncertainty in the face of the global COVID-19 pandemic, education institutions have faced immense challenges as they were forced to transfer the education process to an online format: provide equal access to it for all students, meet teachers' and students' educational needs, and make urgent preparations to support education systems in general and training continuity in particular. The pandemic has also triggered a lot of psychological difficulties such as anxiety, tension, and sadness. The aim of this paper is to describe psychological and pedagogical difficulties in education process during COVID-19 lockdown which serve to take actions and develop definite educational strategies that can be implemented in order to prevent further negative consequences in the system of education. The research is also focused on many effective steps undertaken to the suspension of face-to-face classes at all levels, which can be divided into three main areas of action: the implementation of distance learning modalities across a variety of formats and platforms and the support and mobilization of NGOs. It is proved that virtual education, which is open, attractive, and accessible to everyone plays a meaningful role in creating an information society focused on the improvement of lifelong learning in general and during COVID-19 lockdown in particular. The novelty of the research lies in the analysis of the results of the questionnaire presented to the students and their parents is included. It is an attempt to present the problems which parents and students have to face in the conditions of virtual/remote education.

Keywords: COVID-19 lockdown, education process, educational challenges, psychological difficulties, educational technologies, distance/virtual learning.

DOI: https://doi.org/10.23856/4503

\section{Introduction}

The modern world is saturated with the dynamic technological, economic, civilization and social changes (Huttner:2012; Garrison, Vaughan: 2007). The natural course of life is, on the one hand, inscribed in the unpredictability and lack of stability resulting from different kinds of challenges, and on the other hand, almost unlimited possibilities for students in accessing knowledge, technological novelties, development, action, and work in various places in the 
world without leaving their own home. The innumerable new products and experiences allow them to break traditional boundaries, overcome time, enable spectacular achievements, quick profits, dizzying careers and successes.

The pandemic caused by the SARS-CoV-2 coronavirus, currently experienced by people around the world, is part of the dynamics of changes and unpredictable situations faced by modern world in general and education system in particular. The introduction of numerous restrictions and temporary complete social isolation have resulted in all kinds of difficult pedagogical situations, crises, and traumatogenic experiences, the consequences of which are felt by people around the world, regardless of age, sex, skin color, social status or origin. Investigated by sociologists, psychologists and educators, the consequences of the pandemic serve to take actions and develop definite strategies that can be implemented in order to prevent further negative consequences in education.

The pandemic has also left its mark on the education process. In March 2020, teachers faced the challenge of remote teaching for the first time. As a result, many of them felt pressure as well as distance (caused by fear and lack of skills) to use digital tools. The pandemic lockdown was experienced by all participants of the education process (pupils, students, teachers, parents), and its socio-emotional consequences, read by psychologists and educators, as such that requires immediate intervention, supportive, therapeutic or preventive measures.

The COVID-19 pandemic has caused chaos around the globe. In the field of education, this emergency has resulted in the widespread suspension of face-to-face classes at educational institutions in over 190 countries in order to prevent the virus's spread and mitigate its effects. According to the United Nations Educational, Scientific, and Cultural Organization (UNESCO), more than 1.2 billion students at all levels of education had stopped attending face-to-face classes by mid-May 2020. Over 160 million of these were students in Latin America and the Caribbean. Even before the pandemic, the Economic Commission for Latin America and the Caribbean (ECLAC) argued that the region's social condition was worsening due to increasing poverty and severe poverty rates, persistent inequality, and growing social discontent. In this context, the crisis would have a significant negative effect on various social sectors, including health and education, as well as jobs and poverty. Meanwhile, UNESCO has identified significant inequalities in educational results that are linked to unequal distribution of teachers in general, and of the best trained teachers in particular, to the detriment of low-income countries and regions, as well as rural areas, where indigenous and migrant communities are concentrated (Garrison, Vaughan: 2007). Many of the steps undertaken by the region's countries in response to the crisis in education are related to the suspension of face-to-face classes at all levels, leading to three main areas of action: the implementation of distance learning modalities across a variety of formats and platforms (with or without the use of technology); and the support and mobilization of NGOs.

However, it is thought that, after a brief period of shock and a relatively rapid reorganization of the educational process, various creative ideas, such as special radio lessons, television educational services, and take-home kits, have been developed to support education systems in general and training continuity in particular. Governments and partners around the world, including the UNESCO-founded Global Education Coalition, have created distance learning solutions (Babelyuk 2020:12).

\section{Literature Review}

The COVID-19 crisis is unprecedented phenomenon. It strongly affected international education systems and the poorest and the weakest individuals and societies. The education 
community seems to be resilient however, people and societies risk a downward spiral, because of learning loss and exclusion. This situation requires releasing the potential of individuals and through education investment. Distance learning is an important educational challenge. There is a necessity of meeting the needs of the rapidly evolving knowledge in societies.

An important objective of the virtual teaching is the comprehensive help offered to the student in order to construct his/her own world of values and own information bank. Virtual education environment, which is open, attractive, and accessible to everyone plays a meaningful role in creating an information society focused on the improvement of lifelong learning (Son:2007). The COVID-19 pandemic has caused heavy disruption of education systems and affected about 1.6 billion students in more than 190 countries. Closed schools and other educational entities affected approximately 94 per cent of the students all over the world, while almost 99 per cent in low-income countries. The crisis is deepening education inequalities due to decreased opportunities for students mostly living in poor or rural areas, girls, refugees and other. Economic results connected with pandemia may cause that approximately 23.8 million additional children and youth may not attend school next year. However, this crisis has also contributed to innovations introduced in education. We can observe new, innovative ideas to support educational continuity with use of radio, television, and take-home packages. Distance/ remote learning was developed by governments all over the world including the Global Education Coalition established by UNESCO.

Schools closure for longer periods of time can be devastating. Children particularly in low-income countries of Asia and Africa are more exposed to physical and emotional violence which negatively affects their mental health. Due to the pandemic many students began to believe that they are behind the other and do not meet the requirements the current education system. According to the US Department of Education, the dropout rate been reduced from approximately $10 \%$ in 2006 to ca $5 \%$ in 2018 . Figures for dropouts this school year show a sharp decline in attendance.

Last year, the pandemic caused the necessity of distance instruction. However, there are opinions that students who had issues in accessing the Internet would suffer from severe learning difficulties. Some regions decided to implement individual education. The remote model of learning mostly affects students from the most underdeveloped and underfinanced communities. They are more exposed to unreliable Internet access, as well as their families are more affected by the economic negative impacts of COVID-19. In other words, the world of many learners has changed significantly ((Garrison, Vaughan: 2007; Malanuyk : 2019). It can reduce the position of education in their plans. Concerns about increased drop-out rates can be applied to every major school district. In technical and vocational education as well as training systems, problems in inadequate digitalization and structural weaknesses, have emerged. Disruptions in workplaces complicated apprenticeship projects and work-based learning.

In the higher education institutions online education has been conducted with the use of recorded lectures and online platforms. However, this type of instruction has been abandoned by some universities, due to missing information technology (IT) infrastructure. There are also issues in adjusting semesters and academic calendars, as some programmes can be implemented online, and some cannot. These results may turn out to be rather helpful to policymakers in elaborating strategies aimed at reduction of the consequences of the COVID-19 pandemics.

Professor Oksana Babelyuk and other scholars presented the conditions of remote education in higher education facilities in Ukraine (Babelyuk, Koliasa, Kushlyk, Smaglii :2020). The epidemics of the COVID-19 and lockdown in Ukraine also was a challenge for the national education system. Educators had to focus fully on various E-learning forms of teaching with the 
use of distance edTechs at remote learning such as edTechs of communicative teaching; modular instruction, individualization of learning multilevel (differentiated) training, testing, project, distance education, information, and communication, selecting the elements most appropriate elements for different types of teaching material.

Many higher education facilities such as Department of Germanic Languages and Translation Studies at Drohobych Ivan Franko State Pedagogical University, Department of Foreign Languages and Translation Studies at Lviv State University of Life Safety, Philology Department at Odesa National Maritime University, entered many innovative teaching techniques (Babelyuk, Koliasa, Kushlyk, Smaglii:2020). Among them teaching methods included PowerPoint presentations of lectures and practical lessons, Web-based learning, virtual laboratories, audio-visual aids, video-based demonstrations.

Due to the COVID-19 epidemics, they have elaborated a multi-media remote instruction which enables students to study independently without a conventional classroom which prevents spreading the virus. Universities have developed a variety of instructional media (ITT) into a remote teaching/learning. The instructional media contain textbooks and workbooks mailed to students and supporting media such as audio with scripts, recorded radio and television programs with printed materials and other audio-visual aids. The websites of these universities provide a full range of activities. They comprise a development fund (e.g. to support for small projects); an inquiry service which combine the departments as well as the programs of online conferences, workshops; and online projects dealing with aspects of teaching and learning. During the COVID-19 epidemics, web-based courses were organized solely via the web (ZOOM platform). The main objective was to exclude contact teaching in the cases where the web is used as a support access to study guides and material or online communication between lecturers and students.

One can see positive changes which enable the development of edTechs in Ukrainian universities. The Ministry of Education and Science of Ukraine provided the access to the international databases of Scopus and the Web of Science as well as extended until February 28, 2021, and May 31, 2021, for all state and municipal universities of Ukraine. The expenses are covered by the budget. New analytical tools have become accessible to many institutions (Babelyuk et al.2020: 12).

During the COVID-19 pandemic, students' motivation when learning online has become crucial problem. However, teacher's motivation has not attracted so much attention. Teachers sometimes overlook the importance of this factor in their work. The pressures of the pandemic may have deteriorated the factors affecting teachers to lose motivation. Students are expected to maintain their motivation in learning when different teaching methods are used. It ensures diversity and prevents them from boredom. Students usually represent different styles of learning. Thus, a teacher should meet these needs using different instruction methods. Boring lessons will not contribute to development of students' intrinsic motivation. It can, imply that teachers should consider lecturing to a minimum while applying many teaching strategies that can be more efficient. Teachers build relationships with their students by showing that they care about them. This is a key element to help the learners motivate themselves.

Teacher's motivation is related to student's motivation. Motivated teachers can influence students to study. Students can achieve better or worse results but if teachers are motivated this impact can be more favourable. There are factors which make teachers lose enthusiasm for their work. They sometimes think that they do not encounter sufficient recognition for their work and workload causing stress and demotivation is too heavy. COVID-19 pandemics required to move quickly into an online practice, ensure access to the students, and provide support to 
teachers and students. It caused much stress. These stressful elements can be a reason of mental health challenges. Some of the typical indicators which allow teachers to identify students suffering from mental health difficulties may become unavailable. Teachers may not be meeting their students in person. However, they should attempt to find out how students are doing or how they overcome emotional problems.

Teaching and learning during COVID-19 pandemics strongly depended on the way in which remote instruction learning was provided, the communication methods used by teachers, and their interactions with students. Teachers used to mention the shortcomings of students' equipment as well as their difficulties in using the computer, the Internet or not adequate places to learn. However, the lack of direct contact with students, issues with their activation and mobilization, as well as with controlling their knowledge were listed more often than the lack of appropriate equipment. In the report on research in schools, carried out in May/June 2020, many teachers criticize remote instruction as deteriorating relationships with students and parents, and they also miss direct contacts. The difficulties in distance learning in schools were expected as neither teachers nor students were ready for this form of learning and teaching. Approximately $85 \%$ of teachers had no contact with online teaching before and those who were familiar with the Internet used it for individual communication with students or to participate in webinars.

Currently one can see special opportunity create stronger relationships with students' parents. The existing circumstances may be helpful for their involvement in their children's learning. Families are the best support to students' needs. WhatsApp groups, or virtual meetings are useful for parents to reinforce the role of families in their children's learning. One should realize the stressful situation that families experience, and possibilities created for parents to provide information on their children's learning needs.

Parents who come from different socio-economic backgrounds usually represent different abilities (cognitive and non-cognitive skills) to support their children in their learning at home during COVID-19 pandemics. Parental support can comprise non-financial and financial support. Non-financial support is connected with cognitive and non-cognitive skills. An important factor in this category is amount of time devoted by parents to their children at home. There is an association between parents' and children's cognitive abilities. More educated parents usually dedicate more time to their children and are more involved in their learning.

However, not all parents are familiar with the digital skills needed to assist their children. Those from lower income backgrounds, may not possess essential digital skills. Scholars (Garrison, Vaughan: 2007) claim that computer technology can improve students' learning results only when parents can instruct their children how to use online resources (Brown 2001). Some parents may also represent lower socio-emotional abilities. They may, not appreciate education enough to encourage their children to learn. Students whose parents are more educated usually experience more emotional support then the learners of less educated parents.

\section{Method}

The study included 40 primary school students and 25 parents. It focused on the organization of students' work within distance learning. Further questions are associated with the following issues: how much time students dedicate to completion of the tasks received from their teachers and how they manage with difficulties in very specific conditions. The data included in the survey also analyse what is the impact of isolation on the contacts of students with their 
peers and teachers as well as their moods and mental conditions. The survey also referred to the equipment and its operating by the students and their parents. Parental help is a matter of great importance. Several points of the questionnaire refer to this issue and were addressed both to students and their parents. The survey also focuses on such elements of remote learning as motivation or overloading students with the tasks sent by teachers and other problems that have arisen during distance.

\section{Research}

The conclusions of the conducted survey provided information of the pedagogical and psychological problems encountered by the learners and their parents in time of COVID-19 lockdown. It can be stated that the competences of students and teachers in the usage of information technologies have improved. The surveyed students claimed that they lack relationships with peers and teachers.

Among psychological difficulties we can mention that social isolation may unfavourably influence on such developmental tasks in adolescence, as setting new, more mature associations with peers. Lack of social relations, overloading with lessons and homework can cause negative students' moods. The surveyed students had rather good learning conditions, and adequate IT equipment for remote learning. The survey revealed low activity of students during classes in spite of positive assessments. Teachers argue that this trend can be more intense.

Constant staying at home disturbs the rhythm of the day, which unfavourably affects the functioning of the family members. It may have a negative reflection on the quality of sleep and health (e.g. reduced immunity). Moreover, inappropriate division of time between learning and playing can cause tension and stress. A day of the household should be well balanced as time for studying resting, play and responsibilities is concerned. Disrupting the relationship between individual activities due to interrupted or prolonged learning, may bring to overloading and a significant decline in school achievements. It is very important to have a permanent place to study and take into account the preferences of the children,

\section{Conclusion}

The ongoing COVID-19 pandemic presents major challenges for education systems of different countries and social systems, which must be approached in a coordinated manner. It also teaches important lessons on what matters most in life as a member of educational community. Today, these challenges and lessons offer the possibility of rethinking of the role of the education process in preserving human life and dignity, ensuring that no one is left behind. In other words, as countries explore the best way to deal with uncertainty and reopen their educational institutions safely, this crisis offers a once-in-a-lifetime opportunity to strengthen national education systems and turn them into more equitable and inclusive systems. It also discusses general problems related to teaching and learning education processes in the era of globalization and other issues such as inequality in access to the appropriate educational level. It is proved that quality teaching occurs when teachers plan, develop and assess school environment that includes student-teacher relationships and activities that promote student development. The novelty of the research lies in the analysis of the results of the questionnaire presented to the students and their parents is included. It is an attempt to present the problems which parents and students have to face in the conditions of virtual/remote education. 


\section{References}

Babelyuk O., Koliasa O., Kushlyk O, Smaglii V. (2020). Using Distance EdTech for Remote Foreign Language Teaching During the COVID-19 Lockdown in Ukraine. Arab World English Journal (AWEJ) Special Issue on the English Language in Ukrainian Context, November 2020, Available at SSRN: https://ssrn.com/abstract=3735588 or http://dx.doi.org/10.2139/ ssrn.3735588

Babelyuk, O., Koliasa, O., Lopushanskyy, V., Smaglii, V., Yukhymets,S. (2021). Psychological Difficulties during the Covid Lockdown: Video in Blended Digital Teaching Language, Literature, and Culture.Arab World English Journal (AWEJ) Special Issue on Covid 19 Challenges (1) p. 172-182. DOI: https://dx.doi.org/10.24093/awej/covid.13

Brown, H. (2001). Teaching by principles : an interactive approach to language pedagogy. White Plains, NY: Longman. Brown, J. (1988). Understanding research in second language learning : a teacher's guide to statistics and research design. Cambridge England New York: Cambridge University Press.

Garrison, R. D. \& Vaughan, N. D. (2007). Blended learning in higher education: Framework, principles, and guidelines. San Francisco: Jossey-Bass

Huttner, J. (2012). Theory and practice in EFL teacher education: bridging the gap. Bristol, UK Tonawanda, NY: Multilingual Matters.

Malanuyk, M. (2019). Intersemiotic Translation as a Method of Teaching English to Mentally Handicapped Students. Periodyk Naukowy Akademii Polonijnej w Częstochowie, 35 (4). DOI: DOI: http://dx.doi.org/10.23856/3511 [in English].

Son, J.-B. (2007). Learner experiences in Web-based language learning. Computer Assisted Language Learning. 20(1), p. 21-36. 